All rights reserved. Except for brief quotations used for purposes of scholarly citation, none of this work may be reproduced in any form by any means without written permission from the publisher. For information address the University of Pennsylvania Press, 3905 Spruce Street, Philadelphia, Pennsylvania 19104-4112.

\title{
Evelina, the Rustic Girls of Congreve and Abington, and Surrogation in the 1770s
}

\author{
James E. Evans \\ University of North Carolina, Greensboro
}

In the first volume of Evelina (1778), Frances Burney sends her protagonist to London theaters, among the numerous public venues that provide settings for this "Young Lady's Entrance into the World." Evelina attends several performances at the Theatre Royal in Drury Lane, supposedly at a time when it was managed by David Garrick, who was not only the leading actor of his era, but also Dr. Charles Burney's friend. On her first evening in London, Evelina sees Garrick perform in Benjamin Hoadly's The Suspicious Husband (1747); a week later, in Shakespeare's King Lear. During the most extended of the Drury Lane episodes she sits with friends in a box at a revival of William Congreve's late seventeenth-century comedy Love for Love (1696). Afterwards she writes a letter to her guardian to describe her feelings:

The play was Love for Love, and though it is fraught with wit and entertainment, I hope I shall never see it represented again; for it is so extremely indelicate,- - to use the softest word I can,- - that Miss Mirvan and I were perpetually out of countenance, and could neither make any observations ourselves, nor venture to listen to those of others. ${ }^{1}$

A perfect conduct book lady in this instance, Evelina models John Gregory's advice in A Father's Legacy to His Daughters (1774) that "there are few English comedies a lady can see, without a shock to delicacy." Yet she and Maria Mirvan do not experience a difficulty Gregory warns about: "A virtuous girl often hears very indelicate things with a countenance no wise embarrassed, because in truth she does not understand them." He even recommends that women "avoid these inconveniences" by not attending comedies at all. ${ }^{2}$ Evelina, on the other hand, is genuinely embarrassed, and Burney, who not only enjoyed seeing comedies, but soon wrote them, lets her virtuous heroine be entertained by Samuel Foote's farces The Minor (1760) and The Commissary (1765) later in the novel. 
In writing a much longer episode about Love for Love, Burney not only juxtaposed her comic style and characters with Congreve's, but also entered the decade's conversation about his status on the Georgian stage, a discourse to which another family friend, Richard Brinsley Sheridan, contributed during the theatrical season of 1776-77. Including the episode demonstrated Burney's confidence in her ability as a writer, but her representation incorporated her anxiety as a woman about other matters, including the literary marketplace. ${ }^{3}$ Like her younger heroine, the twenty-five-year-old novelist preferred to be a spectator rather than become an object of attention on London's social stages. And while she lavishes praise on Garrick elsewhere in the novel, she does not even mention Frances Abington, the famous actress who would have been featured in Congreve's play. Wary of the possibility of gazes or laughs directed at women and skeptical about what we now call celebrity, Burney chose, in her first publication, to pursue fame through the anonymity of print.

I want to contextualize Burney's narrative choices by employing Joseph Roach's concept surrogation, which he developed "to examine how culture reproduces and re-creates itself" through a process of transmission that includes "the three-sided relationship of memory, performance, and substitution." $\mathrm{He}$ writes:

In the life of a community, the process of surrogation does not begin or end but continues as actual or perceived vacancies occur in the network of relations that constitutes the social fabric. Into the cavities created by loss through death or other forms of departure ... survivors attempt to fit satisfactory alternates. Because collective memory works selectively, imaginatively, and often perversely, surrogation rarely if ever succeeds. ${ }^{4}$

As authors engage in the "search for originals by continuously auditioning stand-ins," or surrogates, Roach observes, "selective memory requires public enactments of forgetting, either to blur the obvious discontinuities, misalliances, and ruptures or . . . to exaggerate them in order to mystify a previous Golden Age." Writing the performance of Love for Love, Burney joined numerous authors in remembering Congreve's canonical plays, but, unlike many contemporary observers of the stage, she allows readers to forget Abington's roles in them. In addition, she implicitly offers her novel as a substitute for the former and herself as a surrogate for the latter. To understand how her novel participates in this larger cultural process, I examine Congreve's play and Burney's refashioning of it and then explore Abington's theatrical and non-theatrical performances in relation to the novelist's views on theatricality. Finally, I contrast Sheridan's example to offer some conclusions about Burney's selective memory. 


\section{REMEMBERING CONGREVE'S COMEDY AND MISS PRUE}

Love for Love was the third and most popular of Congreve's four comedies. Like many Restoration comedies, it includes courtship, seduction, and cuckolding. Valentine, the prodigal elder son of Sir Sampson Legend, loves the heiress Angelica, who pretends indifference to test him. His brother Ben, a sailor, comes to London for an arranged marriage with another heiress, Miss Prue, daughter of Foresight. Having been raised in the country, Miss Prue finds the foppish Tattle more desirable. Valentine's friend Scandal seduces Foresight's wife, while her sister, Mrs. Frail, first pursues Ben, then Valentine. After Valentine feigns madness and Sir Sampson woos Angelica, she declares her love for the son. Ben returns to sea, and Miss Prue, to the country. Love for Love became, as Shirley Strum Kenny observes, one of the "perennial favorites" of the comic repertory during the next century; according to Mark S. Auburn, between 1747 and 1780 it was performed 105 times at the two principal London theaters. ${ }^{6}$

In the decade before Evelina, both theaters frequently revived Love for Love and, less often, other Congreve plays. These performances began with a notable version at Drury Lane in the 1769-70 season, following a period in which the play, according to the company, was "Not acted in 5 years." Covent Garden had performed the play only twice during that period. This neglect came after a very active decade of production from 1755 to 1764 in which the two companies offered more than forty performances. Although Garrick did not act in it, his 1769 production brought considerable attention to Love for Love through his new casting of the gifted comic actress Abington as Miss Prue, a role so celebrated that Joshua Reynolds, another of Dr. Burney's friends, soon painted her portrait in it; the company performed the play in each of the next two seasons, featuring Abington. This success was followed by a revival at Covent Garden, which staged the play in four subsequent seasons, beginning in 1772-73. Along with these revivals, critics in London periodicals renewed their dialogue about Congreve's status as a dramatist. When Sheridan took over Drury Lane's management, he revived three Congreve comedies during his first season, including Love for Love, with Abington reprising her famous part. ${ }^{7}$ In fact, both theaters performed the play in November and December 1776, when Burney was likely still writing her novel. Sheridan would soon provide his own new play as a substitute for the revival.

By incorporating Love for Love early in Evelina, Burney took advantage of this cultural remembering and replacement. First, she associates her performance with Garrick's management and thus with his revival; this means that the episode, if temporally accurate, takes place no later than the 1771-72 season, or if more imaginatively recalled, before his retirement in 1776. Having set the performance in the recent past, Burney also engages selective memories of Congreve recorded in print culture throughout the 1770s. Evelina's remarks on Love for Love-initial praise of its "wit and entertainment," qualified by its 
being "extremely indelicate" — closely resemble recent critical discussion. Eric Rump records a number of such comments: A writer in The Dramatic Censor (1770) applauds Congreve's "brilliant wit" and "pleasing delineations of life," but deplores "a most abominable vein of licentiousness" in his comedies. A commentator on Love for Love in The Theatrical Review (1771) remarks that such "licentiousness" makes it "the wish of Humanity, and of Virtue, that this Play was consigned to oblivion, with all its merits, on account of this particular." A critic in The London Magazine (1771) judges Congreve's female characters to be "libels upon the very idea of delicacy." Even an admirer of Congreve's "wit and humour" in The Morning Post (1775) finds his work "severely reprehensible for that indelicacy, which the author has made prevail." ${ }^{8}$ Clearly aware of this discourse, Burney has Evelina echo key aspects of it.

As Susan Staves observes, Burney represents in detail the conflict "between the heroine's struggle to preserve her delicacy ... and the multitude of comic characters who constantly threaten it." Evelina's "Entrance into the World" is a search for identity during a liminal period as "nobody," the unacknowledged daughter of Sir John Belmont. The first of her chaperones, Mrs. Mirvan, takes her to London with her daughter and introduces her to genteel friends and urban entertainments; with the Mirvans, Evelina sees Love for Love. Usually meek in company, she records her social life in considerable detail in her letters, mostly addressed to her guardian in Dorsetshire. These accounts detail her responses to events, like attending this play, that challenge her delicacy and threaten public exposure of some kind. Yet Evelina's letters are very different from her modest words or awkward silences when interacting with other characters. Margaret Anne Doody astutely points out that "Her public and enjoined timidity is a veil for the vivid observation, sincere reaction, and shrewd judgment we accept in her letters." Burney, she concludes, uses "the sweet innocent heroine as the implement of the satirist." ${ }^{10}$ Unlike her protagonist, who is shocked by an indelicate play, the novelist willingly engages Congreve's work and current commentary about the dramatist, and Evelina's letters become Burney's vehicle for imagining a surrogate for his type of comedy.

Burney's early diary provides evidence that she was, in Staves's phrase, "more boisterous, more ironic, and more sympathetic to laughter than the decorous Evelina." ${ }^{11}$ Burney records an occasion in August 1778 when Samuel Johnson and Hester Thrale tease her about this discrepancy. Johnson snatches her hand and declares to Thrale of her planned introductions, "Ah! they will little think what a Tartar you carry to them!" Thrale agrees and continues, "Miss Burney looks so meek, \& so quiet,- - nobody would suspect what a comical Girl she is:- -but I believe she has a great deal of malice at Heart." "Oh she's a Toad! . . . a sly Young Rogue!" concludes Johnson. ${ }^{12}$ The image of Burney as a "Tartar," a harsh or fierce person, whose comic sense expresses "malice," makes her sound more like the satirical Congreve than the delicate Evelina. According to Audrey Bilger, Burney solved the problem of a woman's creating laughter in a "sub- 
versive" way, by using the domestic novel as "an acceptable vehicle" through which she expresses her "decided taste for the ridiculous" and creates "the illusion of a private relation between the author and her audience." ${ }^{\prime 13}$ This sly strategy enabled a confident Burney to present stand-ins for some of Congreve's characters. Her refashioning of manners comedy is another instance of the process Doody attributes to her handling of farce, that Burney "seizes a 'masculine' mode of comedy, largely derived from the public medium of the stage, wraps it up in the 'feminine' epistolary mode, and uses the combination for her own purposes." ${ }^{14}$ The novel thus anticipates the rewriting Barbara Darby discovers in Burney's own plays, which contain "examples of the masculinist biases of conventional dramatic representation, instances of the exposure of these biases, and, to some extent, the revision of them."15 This is an important aspect of Burney's contribution to the decade's surrogation of Congreve.

The Love for Love episode demonstrates it well. As Lord Orville and Mrs. Mirvan discuss whether the "entertainment" of the play outweighs its "objections" for women, Captain Mirvan complains: "What, I suppose it is not sentimental enough! . . . or else it's too good for them; for I'll maintain it's one of the best comedies in the language, and has more wit in one scene, than there is in all the new plays put together." ${ }^{\prime 16} \mathrm{His}$ opinion closely resembles a recent reviewer's praise of The Way of the World, in The Morning Chronicle (1775): "Congreve has given as much wit and spirit in one act of this play as would serve to set up twenty such moral spinning poets." Burney's view seems closer to that of a writer in The New Morning Post (1776), who wondered whether audiences "will again relish that male libertinism, which accompanied the masculine genius of Congreve."17 The Captain's admiration of Love for Love raises similar doubts, for Evelina's letters satirize both him and his response to the play. She records being initially "shocked" to meet Mirvan, whom she calls "surly, vulgar, and disagreeable," and finds full of "rude jests." ${ }^{18}$ His brutal treatment of her grandmother does not improve Evelina's opinion.

After they watch the play, Mirvan and Lovel apply Congreve's characterizations of sailor and fop to each other. Mirvan mocks Lovel by asking his opinion of "one Mr. Tattle that is in this play." Lovel retorts by asking the captain "what do you think of one Mr. Ben?" A stern reply compels Burney's fop to turn "in a sneering tone" to the meeker Evelina. Claiming to be taken "with the country young lady, Miss Prue," Lovel inquires, "pray what do you think of her, Ma'am?"19 Burney thus invites application of Congreve's template to her characters assembled at Drury Lane. In addition to the fop, the military man, and the ingénue, the scene includes a man of pleasure, Sir Clement Willoughby, who is somewhat like Congreve's Scandal, but also Lord Orville, who bears little resemblance to Valentine. Though not perfect, Orville would be out of place in Love for Love. His presence epitomizes Burney's variation of manners comedy, deployed in a domestic novel that values sensibility as well as satire. However, like Congreve's comedy, Burney's fiction represents the theatrical- 
ity of London society, in which those who understand its manners have more power. She emphasizes this in the Preface by declaring that her book depicts the heroine's "first appearance upon the great and busy stage of life." ${ }^{20}$ Darby observes of Burney's fiction generally that "the theater provides a metaphor for female experience and the performative aspects of femininity: learned appropriate behavior, movement, manners, and speech." ${ }^{21}$

Central to the Love for Love episode is the distinction between Miss Prue and Evelina, Burney's surrogate for Congreve's young woman. Even the usually obnoxious Sir Clement tells Lovel that "such an object as Miss Prue" would never "engage" Evelina's attention. The fop persists in pointing out that "'tis the first character in the piece!—so well drawn,- -so much the thing!— such true country breeding,-such rural ignorance!"22 Evelina is a country-bred girl, whose ignorance of the town causes difficulties. Reverend Villars calls her "a little rustic," and Madame Duval speaks of her "bumpkinish air"; Evelina judges herself "a simple rustic" at her first ball. ${ }^{23}$ Yet her resemblance to Congreve's character ends with her background and initial ignorance of the town. Miss Prue, identified in the play's Dramatis Personae, as "a silly, awkward country girl," excitedly learns to be a London lady, as instructed by Tattle:

Besides, you are a woman; you must never speak what you think. Your words must contradict your thoughts, but your actions may contradict your words.... If I ask you to kiss me, you must be angry, but you must not refuse me. If I ask you for more, you must be more angry, but more complying. ${ }^{24}$

As Pat Gill points out, Miss Prue "is delighted to find that she can indicate her sexual willingness while denying it, that she is relieved of verbal compliance and, hence, moral responsibility." 25 Yet near the end of Love for Love, disappointed in her desires, she blurts out, "for now my mind is set upon a man, I will have a man some way or other. O! methinks I'm sick when I think of a man, and if I can't have one, I would go to sleep all my life, for when I'm awake, it makes me wish and long." ${ }^{26}$ Evelina is sometimes too direct, as when she first laughs at Lovel, or too silent, when embarrassed, but she does not lie as a policy. She is offended by the hands that Willoughby, Smith, and Lord Merton lay on her, although she blushes when Orville compliments her and tells her guardian that she is "sure you would love him" if they met. ${ }^{27}$

\section{FORGETTING ABINGTON AND THEATRICALITY}

While Burney remembers Miss Prue in some detail, she separates the performer from the part in an act of forgetting. Roach hypothesizes that surrogation demonstrates an "uncanniness" that "tends to disturb the complacency of all thoughtful incumbents" and often results in "ambivalence." ${ }^{28}$ Given the Drury Lane setting for this episode, Burney's characters would have seen Abington 
as Miss Prue. She acted the role in every revival of Love for Love at this theater between 1769 and the publication of Evelina. By then, Abington was long recognized as an accomplished professional and a celebrity. Commenting on her skill "in Thalia's department," one contemporary reports a playwright's opinion that "no actress ever displayed greater proofs of the vis-comica." 29 A foreign visitor believes that Abington "far surpasses all other English actresses in wit"; he also finds her superior in "convincing the innermost heart of the spectators that she does not feel herself to be acting a part, but presenting reality in all its bitter truth." As a result, he concludes, "In comedy, and above all when the manners of the first circles ... are to be parodied, she is unique on the English stage." 30 A fellow actor uses these words about one Abington role: "It is impossible to conceive that more gaiety, ease, humour, elegance, and grace, could have been assumed by any actress than by Mrs. Abington in this part; her ideas of it were entirely her own, for she had seen no pattern." ${ }^{31}$

These commentators convey a good sense of the parts in which Abington excelled, for no actress was more celebrated for manners comedy. Abington began acting in 1755 with a new company at the Haymarket, where her first part was Miranda in Susanna Centlivre's The Busy Body (1709); after a season in Bath, she joined Garrick's Drury Lane company for her first stint, starting out with a role in Congreve's The Double Dealer (1693). After two more seasons, she moved to Dublin, where her performance as Mrs. Sullen in George Farquhar's The Beaux' Stratagem (1707) was the breakthrough that made her a star. Following six successful years on the Irish stage, she rejoined Garrick's company in November 1765 and remained at Drury Lane for seventeen seasons, until leaving for the Covent Garden Theatre for the remainder of her career. Among her parts were numerous appearances in comedies by Farquhar, Congreve, Richard Steele, and Colley Cibber, as well as Beatrice in Much Ado about Nothing and Miss Hoyden in Sheridan's A Trip to Scarborough (1777). Examining the fact that Abington "specialized in the role of the genteel and fashionable young lady," Gillian Russell remarks that "her success in the 1760s and '70s partly derived from the impact of fashionable sociability in public culture as a whole." ${ }^{\prime 32} \mathrm{Her}$ origins made such sociability unlikely for Abington.

The daughter of a cobbler whose mother died when she was fourteen, Abington rose "from the grinding poverty of her origins to the luxury and social distinction which accompanied her success" led to many stories about her, some true, some invented; the previously cited German author alleges that he could write "a small book" about "a woman so remarkable." ${ }^{33}$ After selling flowers and singing songs around Covent Garden or working as a cookmaid or a milliner's assistant, Abington found that success on the stage led her into a different world. Although succeeding in Dublin, where she separated from her husband, her devotion to an Irish member of parliament brought her back to England. When he died, she returned to acting in London, where her celebrity, as in Dublin, extended beyond the theater's walls. In the metropolis, "the public found 
Mrs. Abington delicious. . . Everything she did or said was remarked, especially by women when clothes were concerned. What she dictated, duchesses and dairy maids adopted." Her substantial clothing allowance at Drury Lane allowed Abington not only to be stylish, but to influence the styles of others. A contemporary observer reports that Abington spent "a good part of the day in running about London, to give advice on the dresses and new fashions. She is consulted like a Physician and fee'd in the handsomest manner." ${ }^{\prime 3}$ Such activity helped to make her the talk of the town.

When Reynolds exhibited his portrait of Abington as Miss Prue at the Royal Academy in 1771, he added to her celebrity. He had previously painted a full-length portrait of Abington as Thalia, the comic muse; by representing her in this Congreve role, Reynolds captured more fully her appeal as an actress and a fashion trendsetter. Tate Britain included this portrait in the 2005 exhibition "Joshua Reynolds: The Creation of Celebrity" and displayed it in the room of "Painted Women," pictures which were, according to Martin Postle, Reynolds's "most successful paintings, in terms of the attention that they attracted at the time"; they portrayed "women from the upper echelons of society, whose flagrant sexual conduct flouted polite codes of public behaviour," such as courtesans, actresses, and demireps. In the Abington portrait, Postle argues, Reynolds wanted to paint the complex relationship of the woman and the role: "The point made by Reynolds was that, like Miss Prue, Mrs. Abington is a woman with an appetite for sensual pleasure, and that her success in the role was allied to her own personality." Abington's pose, seated backward on a chair with her thumb before her open lips is, he adds, "at once vulgar and sexually charged." ${ }^{\prime 35}$ However, the sitter's fashionable clothes also evoke Abington's off-stage performances, while Congreve's character was a newcomer to urban style. Postle points out that Reynolds achieved his goal of fame by going beyond its traditional "relationship to honour and virtue" and by "using the mechanisms associated with what has become known as 'celebrity,' a hybrid of fame driven by commerce and the cult of personality." ${ }^{\prime 36}$ This portrait indicates, too, how Abington's personality enabled her commercial appeal, both on the stage and off. According to Roach, she had long embodied "It," which he defines as "the properties shared by abnormally interesting people," whose "fortunate" possessors had "that strange magnetism which attracts both sexes." ${ }^{\prime 37}$

Burney's only reference to Abington in her early journals foreshadows the uncanniness of her later suppression. Out with her sister on a March day nearly three years prior to the publication of Evelina, they "met the celebrated Actress ... walking \& alone, in Tavistock Street." When Susanna "proposed our turning back, \& and following her," they "Traced her Foot steps, which were made very leisurely, as she looked at all the Caps as she passed." Following a celebrity in a favorite shopping pursuit seems strange enough, but the Burney sisters soon encountered Garrick "at the Corner of Charles Street": 
He touched his Hat, \& made a motion towards meeting. Mrs. Abington, who was just before us, returned a Courtesie, \& crossed over to him, While we Walked gravely on, taking no sort of notice of his Bow, which we did not know who was meant for. They went down Charles Street together, \& when we were out of their sight, we again turned..$^{38}$

Confused by Garrick, who later joined Susanna and Frances in friendly chat, they abruptly stopped shadowing Abington. Forced to go "gravely on," they returned to the distance of female propriety. The modest stalker Burney, here a ghostly presence behind Abington, would later turn the latter into a ghost in her novel by failing to acknowledge her performance as Miss Prue. The reasons were as much cultural as personal. As the daughter of a gentleman, she did not want to follow the path of celebrity trod by this actress, who depended on the public to maintain a status well above her origins.

Burney has been described by recent scholars as "torn between paternal adoration, rebellion, a desire for fame, and the need for propriety." ${ }^{\prime 39}$ Within her fiction, Emily Allen argues, Burney aligns "theatrical spectacle . . . with an inappropriate exteriority and ocular excess"; to this the novelist contrasts "a heightened emotional sensibility" and "a subjectivity understood as interior."40 The author representing Evelina and the actor performing Miss Prue epitomize these crucial differences. Abington prospered on spectacle and excess, while Burney prized subjectivity and sensibility. Assessing the cultural implications of actresses, Kristina Straub asserts that their "transgressions tend to question more dangerously the construct of woman as man's submissive opposite. As women whose profession is undeniably public, actresses resisted the assumption that feminine sexuality was the private (and passive) opposite of masculinity." ${ }^{41}$ In her first novel, Burney was willing to criticize the male conduct of Captain Mirvan, Mr. Lovel, Sir Clement, and others, but she was not ready to question female roles openly by identifying with, or even identifying, an actress.

In the months after publication of Evelina, as Burney's authorship became known to others, her circle of friends in Thrale's Streatham salon expanded to include Sheridan and Reynolds, all of whom encouraged her to write for the stage. When Thrale repeats her wish that Burney "go on in a new path . . to write a Comedy," she offers to "assist in spreading the Fame of Miss Burney." As the latter relates this event to her sister Susanna, she adds, "you can't think how I tremble for what all this will end in!-I verily think I had best stop where I am, \& never again attempt writing - for after so much Honour, so much success,- how shall I bear a downfall?" ${ }^{\prime 2}$ While her reflection expresses anxiety, the key word "Honour" suggests a type of fame different from the celebrity that Abington, Sheridan, and Reynolds were cultivating. This more traditional "Fame," in fact, appears in both the dedicatory poem and Preface to Evelina. In the first Burney hopes that "Concealment" of her authorship will protect her 
father's fame; in the second she claims to be "hopeless of fame" from her novel. ${ }^{43}$ Yet publish she did, surely seeking something more than the Preface allows.

When family friend Samuel Crisp, a kind of second father to Burney, learned of Thrale's opinions, he offered Gregory-like advice:

I have been ruminating a good deal on the Obstacles \& difficulties ... that lye directly across YOUR Path ... in the Walk of Comedy—on the most mature Consideration, I do by no means retract the general Principle that produc'd those observations; I will never allow You to sacrifice a Grain of female delicacy, for all the Wit of Congreve \& Vanbrugh put together-the purchase would be too dear." ${ }^{\prime 4}$

In implicit opposition to her previous acts of substitution in Evelina, this emphatic contrast of Congreve's wit with delicacy emphasizes Burney's dilemma. Yet Crisp points not to plays, but to the much more public "Walk" of a dramatist. As Emily Hodgson Anderson observes, "the female playwright, even more than the novelist, is engaged in a profession that assumes a desire for attention and publicity." Because of the broader social interaction required to get plays produced, Burney "faced the challenge of networking with propriety, an oxymoronic concept for the eighteenth-century woman." 45 She was not yet willing to undertake this challenge in 1778, though she did face it soon afterward. She writes to Crisp to express the binary of author and woman that had already influenced the writing and publishing of Evelina: "I would a thousand Times rather forfeit my character as a Writer, than risk ridicule or censure as a Female." ${ }^{46}$

Repressing Abington's presence in Evelina, then, Burney resisted the perceived threat of the theater and of a theatricalized society to a woman's delicacy. Although Abington had been cast as Miss Prue by two of her father's friends and painted in the part by another, the novelist deferred to Dr. Burney's strict expectations for a lady's conduct. If she rebelled by writing and publishing a novel, she kept her authorship secret and excluded the actress from the few actual persons mentioned in it. ${ }^{47}$ Only after the novel's publication did Burney hear Sheridan's wish, supported by Reynolds, that she "write for the stage," a statement accompanied by "encomiums the most flattering" about Evelina. While Reynolds remarks on her "knack at Characters" and her success in "the Dialogue way," Sheridan twice insists that she write "a Comedy." In this conversation Burney also expresses her knowledge of The School for Scandal, deflecting Sheridan's queries by saying she will answer "as candidly as Mrs. Candour." In reflecting on it, she tells Susanna that "if I should attempt the stage,--I think I may be fairly acquitted of presumption ... my many \& encreasing scruples all give way to encouragement so warm from so experienced a Judge." ${ }^{\prime 48}$ Burney called the evening with Sheridan "decisive," and she would soon begin writing plays, though none of her comedies reached the stage during her lifetime. 


\section{SHERIDAN'S REMEMBERING CONGREVE AND ABINGTON}

As a theater manager and ambitious playwright, Sheridan provided substitute versions of Congreve's comedies in his three revivals, which Eric Rump describes as a strategy to prepare audiences for The School for Scandal. According to Rump, Sheridan solved one cultural problem in the revival of Love for Love through an act of forgetting, editing the play to reduce "overt sexual suggestiveness or directness," but still keeping it "very much Congreve's."49 When The School for Scandal premiered in May 1777, reviewers immediately recognized both its resemblance to Congreve's style and its alterations. Rump records, for example, a writer in The Gazetteer (1777) who concludes that Sheridan now qualifies to "dispute Congreve's royal supremacy" on "the throne of dramatic wit." The search for a surrogate could not be more explicit. A later commentator in The Universal Magazine (1785) explores their relationship more fully and applauds Sheridan's refinements: "By The School for Scandal the style of Congreve was again brought into fashion, and sentiment made way for wit, and delicate humour. That piece has indeed the beauties of Congreve's comedies, without their faults." ${ }^{50}$ Like Burney, Sheridan remembers Congreve's comedy to forge his own style, but his approach, as an already successful author, contrasts with the novice Burney's contribution to the surrogation of Congreve, especially in their differing responses to Abington. This contrast also invites some conclusions about her perspective toward this cultural work of the 1770s.

Like Love for Love, The School for Scandal features the threat of cuckolding and a courtship plot. Old Sir Peter Teazle has married a young woman from the country, whom he brings to London. Seeking to be fashionable, she is tempted to have a liaison with Joseph Surface. His brother Charles, like Congreve's Valentine, is a prodigal, but also a generous young man who loves the heiress Maria. Unlike Congreve's play, Sheridan's does not result in seduction or cuckolding, and the difference typifies Georgian comedy. When Joseph's hypocrisy is exposed, this event leads to the reconciliation of Lady Teazle and Sir Peter and Sir Oliver Surface's recognizing the goodness of Charles, who marries Maria. Among Sheridan's characters, she most resembles Evelina, though her role is much less central. Nearly as modest as Burney's protagonist, Maria has little regard for Lady Sneerwell, to whom she declares, "For my part ... wit loses its respect with me when I see it in company with malice." ${ }^{151}$ She repeats her dissatisfaction about scandal to Joseph: "If to raise malicious smiles at the infirmities or misfortunes of those who have never injured us be the province of wit and humour, heaven grant me a double portion of dullness!"52 Attentive to the cruelty of ridicule, Maria justifies contemporary praise of Sheridan's "delicate humour." Her words are echoed by Sir Peter, who opines that "true wit is more nearly allied to good nature." ${ }^{\prime 3}$ While Sheridan writes comedies that are "consistently witty," John Loftis asserts, his revision of Congreve expresses "a greater tolerance and kindliness in handling aberrations from prudent and 
rational norms of conduct. ${ }^{154}$ Where Burney sweetened the malice that Thrale and Johnson observed through her modest heroine's character, Sheridan signaled his departure from Congreve's more biting comedy with amiable figures like Sir Peter.

Moreover, Sheridan wrote the part of Lady Teazle to highlight Abington's comic talents, for he counted on her celebrity and the public's familiarity with her well-known roles to draw audiences. Russell calls this part "her apotheosis," the culmination of a career in which "the theatricality of the fine lady and the actress's celebrity seemed to meet in her." 55 In reviving Congreve's comedies at Drury Lane, Sheridan cast Abington not only as Miss Prue but also as the sophisticated Millamant in The Way of the World (1700) (as well as Laetitia in The Old Bachelor [1693]). Lady Teazle combines elements of Millamant with the rusticity of Miss Prue, yet finally demonstrates more sentiment than either. Sir Peter calls her "a girl bred wholly in the country," who, like Miss Prue, enjoys "her part in all the extravagant fopperies of the fashion and the town." ${ }^{16}$ Yet Lady Teazle tartly rebukes him for trying to control her: "Authority! . . . if you wanted authority over me, you should have adopted me and not married me; I am sure you were old enough." ${ }^{57}$ When Joseph tries to seduce her, Lady Teazle states that she will accept him "no further than fashion sanctions" and retains "much of my country prejudices." ${ }^{58}$ As her rural background helps her see through sophistication, she finally resembles Evelina more than Miss Prue, who embraces the first sophisticate she meets. Later Lady Teazle describes what she has learned about coping with London, saying that Sir Peter's "tenderness ... has penetrated so to my heart, that ... my future life should have spoken the sincerity of my gratitude. ${ }^{\prime 59}$ Her language is not the stuff of Congreve's comedies. It expresses the sensibility of the 1770s, which inflects Burney's novel as much as Sheridan's play. While Congreve makes readers skeptical of his characters' sincerity, Sheridan's and Burney's better characters epitomize it.

If The School for Scandal retains more of the masculine wit of Congreve than Evelina, both writers participate in the process of surrogation of the canonical writer's plays by remembering him in similar ways, reducing overt sexuality and substituting a rustic heroine who can resist London's gentlemen. Both works possess humor that heeds Lord Orville's warning that "Generosity without delicacy, like wit without judgement, generally give as much pain as pleasure." ${ }^{\prime 60}$ Evelina accomplishes this balance through the dialogism that is characteristic of the novel as a genre. In The School for Scandal Sheridan's more unified style results from his evocation of Congreve's wit in a five-act play, though he draws on other features of Georgian comedies. By staging Congreve's plays, he prepared for reception of a wittier comedy than most others recently on the stage, just as Burney's inclusion of a performance of Love for Love alerted readers to her intervention in the discourse about Congreve.

More than eighty years after its initial performance, Congreve's play remained a valuable touchstone for new comic forms, subject to selective cul- 
tural memory and to numerous auditions for stand-ins. Frances Abington, so integral to Georgian revivals of Congreve, was a touchstone of another kind, especially in ways that show how surrogation may sometimes be a gendered process. For Sheridan, her performances and celebrity were crucial to the success of his own theatrical career. For Burney, these qualities were threats to be avoided while seeking fame on her own terms. This difference, along with her desire to praise Garrick, may explain why she set the Love for Love episode earlier in the 1770s, rather than making it more contemporary with the completion and publication of the novel, after Sheridan became manager of Drury Lane. Burney's choice may be another instance of the uncanniness found in surrogation, for she thus also suppresses the ambitious Sheridan, whether faulting him for featuring Abington or hiding his rivalry and pursuit of celebrity among those creating stand-ins for Congreve's plays. In either case, in writing Evelina, she forgot to name one Frances as a character, just as, in publishing it, she hid her own name. The only identified traces that remained of either woman were their rustic girls, Miss Prue and Evelina.

\section{NOTES}

1. Frances Burney, Evelina: or The History of a Young Lady's Entrance into the World, ed. Margaret Anne Doody (London, 1994), 87.

2. John Gregory, "A Father's Legacy to His Daughters," Women in the Eighteenth Century: Constructions of Femininity, ed. Vivien Jones (London, 1990), 44-53, 48.

3. For an overview of this subject, see George Justice, "Burney and the Literary Marketplace," The Cambridge Companion to Frances Burney, ed. Peter Sabor (Cambridge, 2007), $147-62$.

4. Joseph Roach, Cities of the Dead: Circum-Atlantic Performance (New York, 1996), 2-3.

5. Roach, Cities, 3.

6. Shirley Strum Kenny, "Perennial Favorites: Congreve, Vanbrugh, Cibber, Farquhar, and Steele," Modern Philology 73 (1976): S4-S11; Mark S. Auburn, "Theatre in the Age of Garrick and Sheridan," Sheridan Studies, ed. James Morwood and David Crane (Cambridge, 1995), 7-46, 17.

7. The London Stage 1660-1800: A Calendar of Plays, Entertainments \& Afterpieces Together with Casts, Box-Receipts and Contemporary Comment, Part 4: 1747-1776, ed. George Winchester Stone, Jr., (Carbondale, 1962), 1444, 1511, 1585, 1720, 1798, 1891, 1972; Part 5: 1776-1800, ed. Charles Beecher Hogan (Carbondale, 1968), 37, 40, 48, 81.

8. Quoted in Eric Rump, "Sheridan, Congreve and The School for Scandal," Sheridan Studies, 58-70, 59, 60, 61, 62. Although Burney represents Lord Orville as being in "excellent spirits," consistent with enjoyment, he says of the "Ladies" that "this is not a play that can be honoured with their approbation" (Burney, Evelina, 87, 89).

9. Susan Staves, "Evelina; or, Female Difficulties," Modern Philology 73 (1976): 368-81, 376.

10. Doody, Frances Burney: The Life in the Works (New Brunswick, 1988), 47, 43. Kristina Straub also remarks on Evelina's "observer status" as "an amused and detached spectator." She writes, "The joke ... is that Evelina stands apart from institutionalized triviality—as country girl come to the city—while men enthusiastically promote the economic enterprise of women's trivial pursuits" (Divided Fictions: Fanny Burney and Feminine Strategy [Lexington, Ky., 1987], 105-6).

11. Staves, 377. 
12. Burney, The Early Journals and Letters of Fanny Burney, 12 vols., ed. Lars E. Troide, et al. (Montreal, 1987- ), 3:89.

13. Audrey Bilger, Laughing Feminism: Subversive Comedy in Frances Burney, Maria Edgeworth, and Jane Austen (Detroit, 1998), 28, 29.

14. Doody, 48.

15. Barbara Darby, Frances Burney Dramatist: Gender, Performance, and the Late-Eighteenth-Century Stage (Lexington, Ky., 1997), 11.

16. Burney, Evelina, 89.

17. Quoted in Rump, 62, 66.

18. Burney, Evelina, 42.

19. Burney, Evelina, 90.

20. Burney, Evelina, 7.

21. Darby, 165.

22. Burney, Evelina, 91.

23. Burney, Evelina, 20, 75, 33.

24. William Congreve, Love for Love, ed. Emmett L. Avery (Lincoln, 1966), 11, 57-58.

25. Pat Gill, Interpreting Ladies: Women, Wit, and Morality in the Restoration Comedy of Manners (Athens, Ga., 1994), 117.

26. Congreve, 124.

27. Burney, Evelina, 80.

28. Roach, Cities, 2.

29. Theatrical Biography: or, Memoirs of the Principal Performers of the Three Theatres Royal, 2 vols. (London, 1772), 1:11, 15.

30. Georg Christoph Lichtenberg, Lichtenberg's Visits to England as Described in his Letters and Diaries, trans. Margaret L. Mare and W. H. Quarrell (New York, 1966), 33, 68-69.

31. Tom Davies, quoted in Philip H. Highfill, Jr., Kalman A. Burnim, and Edward A. Langhans, "Abington, Mrs. James, Frances, née Barton 1737-1815, actress," A Biographical Dictionary of Actors, Actresses, Musicians, Dancers, Managers E Other Stage Personnel in London, 1660-1800, 16 vols. (Cardondale, 1973-1993), 1:12-20, 17. I rely on the Biographical Dictionary for subsequent facts about Abington.

32. Gillian Russell, Women, Sociability and Theatre in Georgian London (Cambridge, 2007), 128.

33. Highfill, et al., 12; Lichtenberg, 33.

34. Highfill, et al., 18.

35. Martin Postle and Mark Hallett, "Catalogue," Joshua Reynolds: The Creation of Celebrity, ed. Postle (London, 2005), 71-269, 181, 190. Entries in the "Catalogue" are written by either Postle or Hallett; those quoted here were written by Postle.

36. Postle, "'The Modern Apelles': Joshua Reynolds and the Creation of Celebrity," Joshua Reynolds, 17-33, 17.

37. Roach, It (Ann Arbor, 2007), 4.

38. Burney, Early Journals, 2:94.

39. Darby, 4.

40. Emily Allen, “Staging Identity: Frances Burney's Allegory of Genre," EighteenthCentury Studies 31 (1998): 433-51, 435, 434.

41. Straub, Sexual Suspects: Eighteenth-Century Players and Sexual Ideology (Princeton, 1992), 89. See also Felicity Nussbaum, "Actresses and the Economics of Celebrity, 1700 1800," Theatre and Celebrity in Britain, 1660-2000, ed. Mary Luckhurst and Jane Moody (New York, 2005), 148-68.

42. Burney, Early Journals, 3:161-62.

43. Burney, Evelina, 3, 9.

44. Burney, Early Journals, 3:238.

45. Emily Hodgson Anderson, "Staged Insensibility in Burney's Cecilia, Camilla, and 
The Wanderer: How a Playwright Writes Novels," Eighteenth-Century Fiction 17 (2005): 629-48, 632-33.

46. Burney, Early Journals, 3:212.

47. While Burney elaborately maps the London terrain, she does not identify many living persons; those she does are all male (in addition to Garrick and Samuel Foote, magistrate John Fielding, opera star Giuseppe Millico, fireworks director Giovanni Battista Torré, and violinist François-Hippolyte Barthélemon [Burney, Evelina, 57, 102, 259]).

48. Burney, Early Journals, 3:234-36.

49. Rump, 65. As Rump observes, "the overnight liaison between Scandal and Mrs. Foresight is quietly dropped and whereas in Congreve Tattle asks Prue to show him where her 'bed-chamber' is, in Sheridan this becomes the slightly more decorous 'dressing-room'" (65).

50. Quoted in Rump, 68.

51. Richard Brinsley Sheridan, The School for Scandal and Other Plays, ed. Rump (London, 1988), 195.

52. Sheridan, 215.

53. Sheridan, 214.

54. John Loftis, Sheridan and the Drama of Georgian England (Cambridge, Mass., 1977), 10, 99. For a different perspective, see James Thompson, "Sheridan, The School for Scandal, and Aggression," Comparative Drama 42 (2008): 89-98.

55. Russell, Women, Sociability, 128.

56. Sheridan, 203.

57. Sheridan, 206.

58. Sheridan, 216-17.

59. Sheridan, 257.

60. Burney, Evelina, 91. 
Copyright of Eighteenth Century: Theory \& Interpretation (University of Pennsylvania Press) is the property of University of Pennsylvania Press and its content may not be copied or emailed to multiple sites or posted to a listserv without the copyright holder's express written permission. However, users may print, download, or email articles for individual use. 